\title{
Article
}

\section{Phytophthora elongata (Peronosporaceae) is present as an estuarine species in Philippine mangroves}

\section{Bennett RM ${ }^{1,2, ~ *}$, Dedeles $\mathrm{GR}^{4}$, and Thines $\mathrm{M}^{1,2,3}$}

\author{
${ }^{1}$ Senckenberg Biodiversity and Climate Research Centre, Senckenberg Gesellschaft für Naturforschung, \\ Senclenberganlage 25, 60325 Frankfurt am Main \\ ${ }^{2}$ Department of Biosciences, Institute of Ecology, Evolution and Diverstiy, Goethe University Frankfurt am Main, Max- \\ von-Laue-Straße 9, 60438 Frankfurt am Main, Germany \\ ${ }^{3}$ Integrative Fungal Research Cluster (IPF), Georg-Voigt-Straße 14-16, 60325 Frankfurt am Main, Germany \\ ${ }^{4}$ UST Collection of Microbial Strains, Research Centre for the Natural and Applied Sciences, University of Santo \\ Tomas, Manila, Philippines
}

Bennett RM, Dedeles GR, Thines M 2017 - Phytophthora elongata (Peronosporaceae) is present as an estuarine species in Philippine mangroves. Mycosphere 8(7), 959-967, Doi 10.5943/mycosphere/8/7/11

\begin{abstract}
The genus Phytophthora, a group of hemibiotrophic oomycetes, is composed of almost 150 species, most of which are pathogens of terrestrial and freshwater plant species. Of the known taxa of Phytophthora, three species (P. estuarina, P. gemini, and P. rhizophorae) were only recorded in the estuarine or marine environment, while others were recently discovered to be present in these environments as saprotrophs, suggesting that more Phytophthora species might be present in marine or estuarine habitats. Thus, mangrove habitats of the Philippines were surveyed for additional Phytophthora species apart from the previously-reported species, Phytophthora insolita. As a result, Phytophthora elongata, which was reported as a pathogen of Eucalyptus marginata from Western Australia, was isolated from mangrove leaf litter in the coastal area of Cavite, Philippines, as the first Clade 2 species found in saline habitats. This suggests that among Phytophthora species there is the potential to rather easily evolve measures to deal with osmotic pressure, which supports the potential importance of mangroves as a cryptic habitat of Phytophthora.
\end{abstract}

Key words - Estuarine environment - Halophytophthora - Mangroves - Oomycetes Peronosporaceae - Phytophthora

\section{Introduction}

The genus Phytophthora, a member of the family Peronosporaceae (Thines et al. 2009, Hulvey et al. 2010, Thines 2014), contains hemibiotrophic pathogens that have mostly been isolated from infested plants, freshwater, or soil (Kroon et al. 2012, Hyde et al. 2014). In molecular phylogenies, the genus can be divided into 8 to 10 clades with overlapping morphological characteristics (Cooke et al. 2000, Blair et al. 2008, Runge et al. 2011). Ho and Jong (1990) described Halophytophthora to accommodate Phytophthora-like species that are striving in an estuarine or marine environment and in subsequent years several filamentous oomycetes from estuarine or marine environments were added to the genus, rendering it increasingly heterogeneous (Hulvey et al. 2010). However, phylogenetic analyses using several markers strongly inferred the 
polyphyly of Halophytophthora (Hulvey et al. 2010, Lara \& Belbahri 2011) and as a consequence some species were transferred to other genera, such as Phytopythium (Phytopythium kandeliae, basionym H. kandeliae) (Thines 2014), Salisapilia (S. tartarea, basionym H. tartarea) (Hulvey et al. 2010), and Salispina (S. spinosa and S. lobata, basionyms Phytophthora spinosa var. spinosa and P. spinosa var. lobata, respectively) (Guo et al. 2016). The primary concept of Halophytophthora as a genus containing marine or estuarine Phytophthora-like species is thus no longer applicable. Also, there are reports on the occurrence of genuine species of Phytophthora sensu lato in marine and estuarine systems (i.e. P. estuarina, $P$. gemini, $P$. inundata, $P$. insolita and P. rhizophorae) (Zeng et al. 2009, Man In'T Veld et al. 2011, Guo et al. 2016, Bennett \& Thines 2017). Further, Preuett et al. (2016) demonstrated the survival of $P$. ramorum on media with varying salinity, supporting the conclusion of Duniway (1979) that Phytophthora spp. might generally have some tolerance for salinity. Because of the increasing evidence that oomycete species, including Phytophthora species, are common inhabitants of marine and estuarine environments similar to true fungi (Jones et al. 2015), it was the aim of the current study to survey mangrove habitats of the Philippines for the potential presence of additional species of Phytophthora.

\section{Materials \& Methods}

\section{Isolation and sporulation}

Fallen senescent mangrove leaves from the coastal area of Cavite, Philippines were collected. Leaves were blot dried, cut into strips $(\sim 5.0 \times 0.2 \mathrm{~cm})$, and laid over onto clarified vegetable juice agar (VJ) (0.2 $1 \mathrm{~V} 8^{\circledR}$ Juice, Campbell, $1.5 \%$ agar in 0.81 distilled water or half-strength sea water) amended with $500 \mathrm{mg} / \mathrm{ml}$ Nystatin, $30 \mathrm{mg} / \mathrm{ml}$ Rifampicin or $0.5 \mathrm{mg} / \mathrm{ml}$ Streptomycin. Hyphae growing from the periphery of the leaf strips were cut and transferred to a new VJ agar until axenic. Agar blocks $\left(\sim 0.5 \mathrm{~cm}^{2}\right)$ with mycelia from axenic cultures were either placed in $0-30 \mathrm{ppt}$ aqueous sea salt solution, sterile or unsterile soil extract, or a combination of both for the production of sporangia and release of zoospores.

\section{DNA extraction and Phylogenetic analyses}

The strains BMYL-1217-1 and BMYL-1217-2 recovered from the leaf samples were incubated on $\mathrm{VJ}$ agar for 7 to 10 days at room temperature in the dark. After this, mycelia from the agar plates were harvested by tearing it off using forceps and homogenized in $2 \mathrm{ml}$ reaction tubes with $600 \mu$ l extraction buffer $(50 \mathrm{mM}$ Tris $\mathrm{pH} 8,200 \mathrm{mM} \mathrm{NaCl}, 0.2 \mathrm{mM}$ EDTA, 0.5\% SDS, 100 $\mathrm{mg} / \mathrm{ml}$ Proteinase K, and $100 \mathrm{mg} / \mathrm{ml}$ glycogen) using a mixer mill (Retsch MM 200, Retsch GmbH, Haan, Germany). The homogenized lysate was incubated at $60{ }^{\circ} \mathrm{C}$ for 30 minutes with shaking at $850 \mathrm{rpm}$ for 5 seconds in every 2 minutes in a Thriller® device (VWR peqlab, Erlangen, Germany). Subsequently, $600 \mu$ l of phenol-chloroform-isoamyl alcohol (25-24-1, Roti® Carl Roth, Karlsruhe, Germany) was added and tubes were centrifuged at 19,000 $\mathrm{g}$ for 10 minutes. Afterwards, $500 \mu \mathrm{l}$ of the supernatant were transferred to a new tube and $5 \mu \mathrm{l}$ of $20 \mathrm{mg} / \mathrm{ml} \mathrm{RNase}$ A solution was added. Subsequently, the tubes were incubated at $37{ }^{\circ} \mathrm{C}$ for 30 minutes. Then $600 \mu \mathrm{l}$ phenol-chloroformisoamyl alcohol solution (25-14-1) were added and the tubes were centrifuged at 19,000 $\mathrm{g}$ for 10 minutes. The supernatant was transferred to a new tube and another $600 \mu 1$ of phenol-chloroformisoamyl alcohol solution (25-24-1) was added. This was followed by centrifugation at $19,000 \mathrm{~g}$ for 10 minutes. Afterwards, the supernatant was transferred to a new tube. Subsequently, $45 \mu 1$ of $3 \mathrm{M}$ sodium acetate at $\mathrm{pH} 5.3$ and $1,000 \mu \mathrm{l}$ of ethanol were added. Tubes were mixed carefully for 30 seconds and then incubated at $-20^{\circ} \mathrm{C}$ for 30 minutes. After incubation, DNA was pelleted at 6,000 $g$ for 10 minutes and the supernatant was discarded. Ethanol (70\% volumetric in water) was added to the DNA pellets and tubes were subsequently centrifuged at $6,000 \mathrm{~g}$ for 2 minutes. This step was repeated twice. Finally, DNA pellets were dried in a Thriller ${ }^{\circledR}$ at $60{ }^{\circ} \mathrm{C}$ for 10 minutes and $30 \mu 1$ molecular grade distilled water was added to dissolve the purified DNA. 
The DNA solutions were quantified using an IMPLEN Nanophotometer (Implen GmbH, Munich, Germany). Approximately $10-50 \mathrm{ng}$ of DNA were used per PCR reaction for the amplification of the Internal Transcribed Spacers (ITS) and cytochrome oxidase 1 (cox1) regions using the primer pairs listed in Table 1 . The PCR reaction mix contained $1 \times$ PCR buffer, $0.2 \mathrm{mM}$ dNTPs, $2.0 \mathrm{mM} \mathrm{MgCl}, 0.8 \mu \mathrm{g}$ BSA, $0.4 \mu \mathrm{M}$ of each primer, $0.5 \mathrm{u}$ Taq polymerase and $10-50 \mathrm{ng}$ DNA.

Table 1 Primer pairs used in PCR amplification.

\begin{tabular}{llll}
\hline Loci & Primer name & Primer sequence $\left(\mathbf{5}^{\prime}-\mathbf{3}^{\prime}\right)$ & Reference \\
\hline ITS & ITS1-O & CGG AAG GAT CAT TAC CAC & Bachofer 2004 \\
& LR0 & GCT TAA GTT CAG CGG GT & Moncalvo et al. 1995 \\
cox1 & OomCoxl_Levup & GCT TAA GTT CAG CGG GT & Robideau et al. 2011 \\
& OomCoxl_Levlo & CYT CHG GRT GWC CRA AAA ACC AAA & Robideau et al. 2011 \\
\hline
\end{tabular}

Cycling conditions for the ITS region included an initial denaturation at $94{ }^{\circ} \mathrm{C}$ for 4 minutes, followed by 36 cycles of denaturation at $94{ }^{\circ} \mathrm{C}$ for 40 seconds, annealing at $55^{\circ} \mathrm{C}$ for 20 seconds, and elongation at $72{ }^{\circ} \mathrm{C}$ for 60 seconds. Subsequently, a final elongation at $72{ }^{\circ} \mathrm{C}$ for 4 minutes was carried out. The cycling program for the $\operatorname{cox} 1$ region included an initial denaturation at $95{ }^{\circ} \mathrm{C}$ for 4 minutes, followed by 36 cycles of denaturation at $95{ }^{\circ} \mathrm{C}$ for 40 seconds, annealing at $51{ }^{\circ} \mathrm{C}$ for 40 seconds, and elongation of $72{ }^{\circ} \mathrm{C}$ for 60 seconds. Subsequently, a final elongation was done at 72 ${ }^{\circ} \mathrm{C}$ for 5 minutes. All PCR reactions were performed in an Eppendorf Mastercycler Pro Thermocycler equipped with a vapoprotect lid (Eppendorf AG, Hamburg, Germany).

PCR products were sent to the sequencing laboratory of the Senckenberg Biodiversity and Climate Research Centre, using the reverse primers of each amplified region. Obtained sequences were edited using Geneious, version 5.0.4 (Biomatters Ltd., Auckland, New Zealand). The edited sequences were uploaded to the TrEase webserver (http://www.thines-lab.senckenberg.de/trease/) (Mishra et al. unpublished) together with the other sequences obtained from GenBank (www.ncbi.nlm.nih.gov/genbank/) and from the Phytophthora database (www.phytophthoradb.org) for sequence alignment and phylogenetic tree construction using Bayesian Inference (BI) with MrBayes (Ronquist et al. 2012) following the standard settings implemented in siMBa (Mishra and Thines 2014). MAFFT (Katoh et al. 2002) was used for alignments, choosing the G-INS-I algorithm for the ITS sequences and FFT-NS-1 (fast) for the cox1 sequences (applicable because of the lack of gaps in cox 1 sequence alignments in the closely related species included in this study). Two additional phylogenetic methods were used alongside with Bayesian Inference (BI) as the primary phylogenetic tree. Maximum Likelihood (ML) inference was done using FastTree 2 (Price et al. 2010) and Minimum Evolution (ME) inference was done using MEGA version 6 or 7 (Tamura et al. 2013). For Bayesian inference, the 6 GTR substitution model was the chosen model and 1,000,000 generations with incrementally heated chains were calculated with sampling at every $10,000^{\text {th }}$ tree and discarding the first $30 \%$ of the sampled trees. For Maximum Likelihood (ML) inference, the GTR substitution model was chosen and 1,000 bootstrap replicates were performed. For Minimum Evolution (ME) inference, the Tamura-Nei model was used as this is the most complex standard model offered by MEGA, version 6 and 7, performing 1,000 bootstrap replicates. All other settings were set to default. All phylogenetic trees were viewed in MEGA, version 6 or 7 .

\section{Results}

The strains Phytophthora BMYL-1217-1 and BMYL-1217-2 were similar in morphology in both sporangia (i.e. shape, zoospore release, branching patterns, and proliferation) and gametangia with morphological features agreeing with the description of $P$. elongata. The morphological features of the strains are depicted in Figure 1. Both strains are homothallic, i.e. capable of producing antheridia and oogonia in the absence of an opposite mating type, and gametangia are 
readily produced in vegetable juice agar media with or without seawater when incubated at room temperature. Antheridia are paragynous, and oogonia are spherical with aplerotic oospores, i.e. space is present between the oogonium wall and oospore wall (Figure 1). Sporangia were produced when agar blocks from 7 to 10 day-old cultures were placed in unsterile soil extract and incubated at room temperature. Sporulation was not observed in saline solutions. The shape of the sporangia is ovate to obpyriform. Sporangia were non-caducous and apapillate. Based on ITS and cox 1 phylogenies (Figures 2 and 3, respectively), strains BMYL-1217-1 and BMYL-1217-2 belonged to the Clade 2 of Phytophthora sensu lato, and are grouped with the identical sequence from the extype culture of $P$. elongata (CBS 125799) with strong support in all analyses.
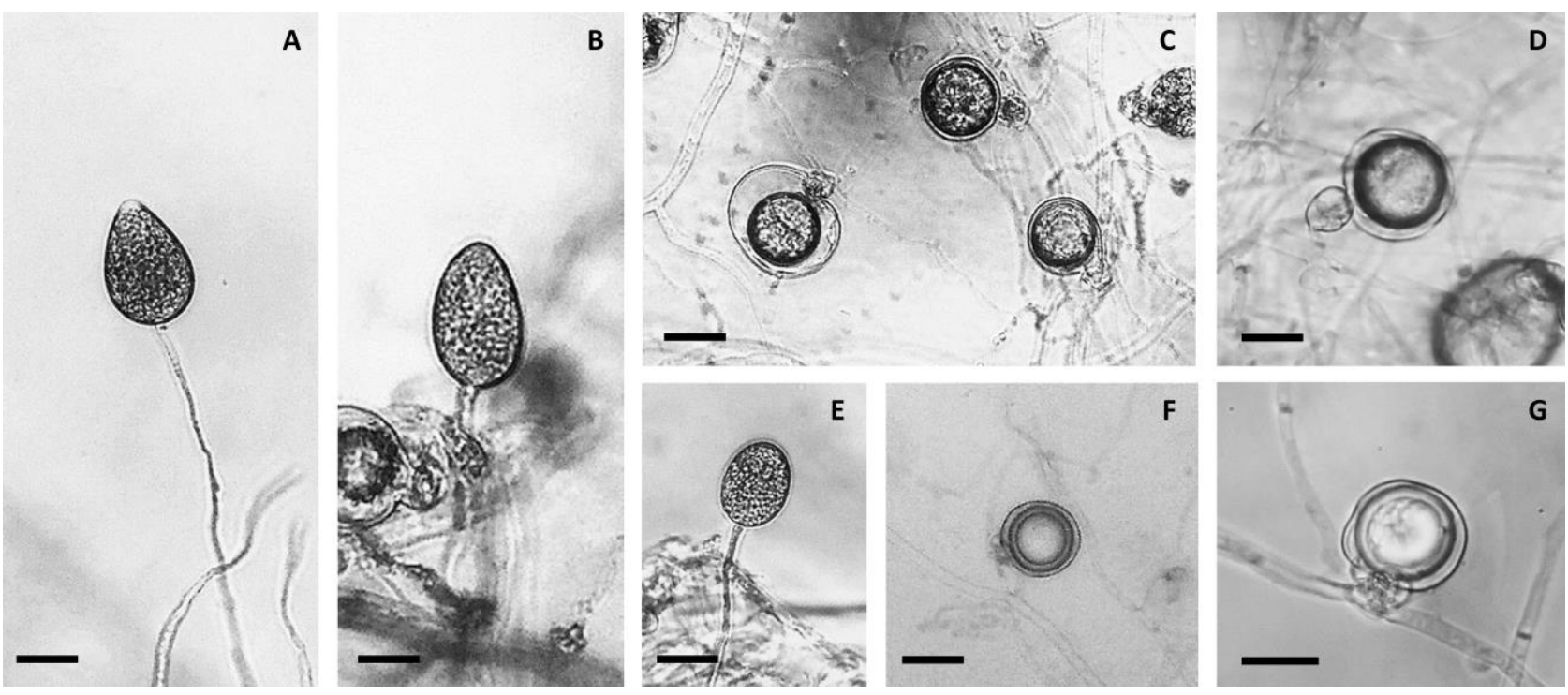

Figure 1 - Phytophthora elongata. BMYL-1217. A, B, E Sporangia. C, D, F, G Gametangia. Note the presence of the paragynous antheridia; Oospores, aplerotic. Scale bars $=20 \mu \mathrm{m}$.

\section{Discussion}

The knowledge of Phytophthora in the Philippines is limited and the majority of reports are from post-harvest fruits and agricultural fields. However, a single species has so far been reported as a saprotroph on mangrove leaves, $P$. insolita (Bennett \& Thines 2017). The phytopathogenic Phytophthora spp. reported in the Philippines are listed in the review of Portales (2004), these include $P$. cactorum, $P$. capsici, $P$. citrophthora, $P$. colocassiae, $P$. haveae, $P$. infestans, $P$. meadii, $P$. nicotianae, $P$. palmivora, and $P$. phaseoli. Herewith, an additional species, $P$. elongata, is reported from an estuarine environment in the Philippines and as the first species of the Clade 2 group of Phytophthora in an estuarine environment.

Classical identification of Phytophthora is often based on the key of Waterhouse (1963) or the revised key of Stamps et al. (1990). With the advent of molecular phylogenetics, the Waterhouse and Stamps classification system of Phytophthora was revealed not to delineate monophyletic entities. Thus, a phylogenetic classification system with 8 to 10 clades is now widely applied (Cooke et al. 2000, Kroon et al. 2004). In this manuscript, the 10 clade classification system is followed as summarized in Kroon et al. (2012). Each of the proposed clades (1 - 10) of Phytophthora sensu lato does not possess obvious consensus morphology with clade-specific synapomorphies. Cooke et al. (2000) proposed that the morphology and phylogeny of the genus Phytophthora should be reanalysed and that naming one or more genera might be considered. A multigene phylogeny using both mitochondrial and nuclear DNA sequences representing 113 isolates from 48 species by Kroon et al. (2004) supported a division of Phytophthora spp. into 8 clades, while Blair et al. (2008) proposed a division of 10 well-supported clades. Runge et al. (2011) inferred a high degree of paraphyly of Phytophthora spp. when two downy mildew species (Pseudoperonospora cubensis and Hyaloperonospora arabidopsidis) were included in the dataset 
of Blair et al. (2008). In their analysis, the downy mildews were placed within clade 4 of Phytophthora. Thus, Runge et al. (2011) seconded the proposal of Cooke et al. (2000) and concluded that it might be necessary to introduce at least six new genera within Phytophthora sensu lato (including clade 2) to resolve the paraphyly of the genus. However, none of the subsequent studies attempted to propose new generic names for some clades of Phytophthora due to the difficulty of finding synapomorphies.

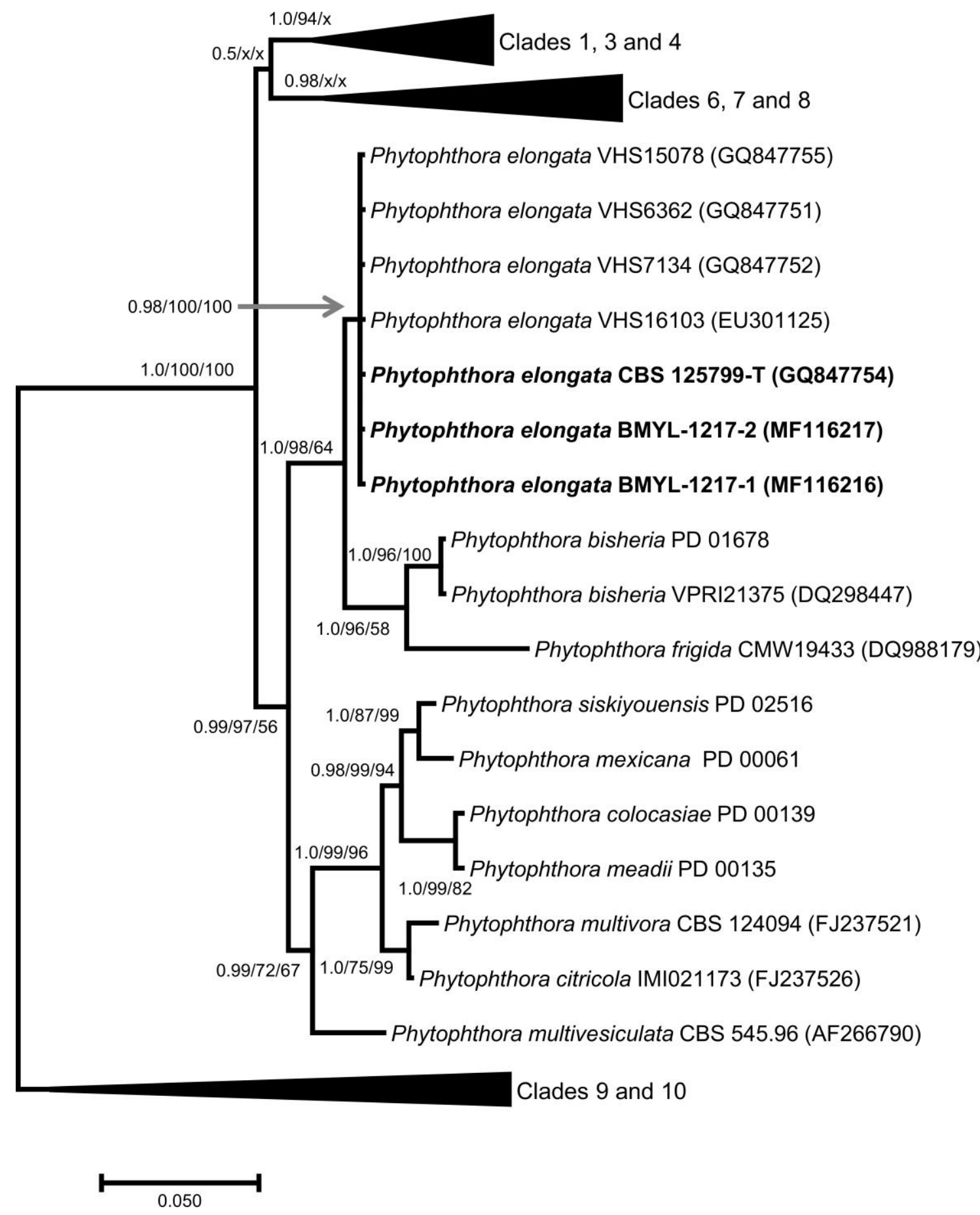

Figure 2 - ITS-based Bayesian phylogenetic inference of the genus Phytophthora. Support values from Bayesian inference, Maximum Likelihood, and Minimum Evolution, in the respective order. CBS 125799 (= VHS13482) is the ex-type culture of P. elongata, while the strains BMYL-1217-1 and BMYL-1217-2 are from the Philippines. The scale bar indicates the number of substitutions per site. $(x)$ indicates support for an alternate topology in comparison to the tree derived from Bayesian inference. 


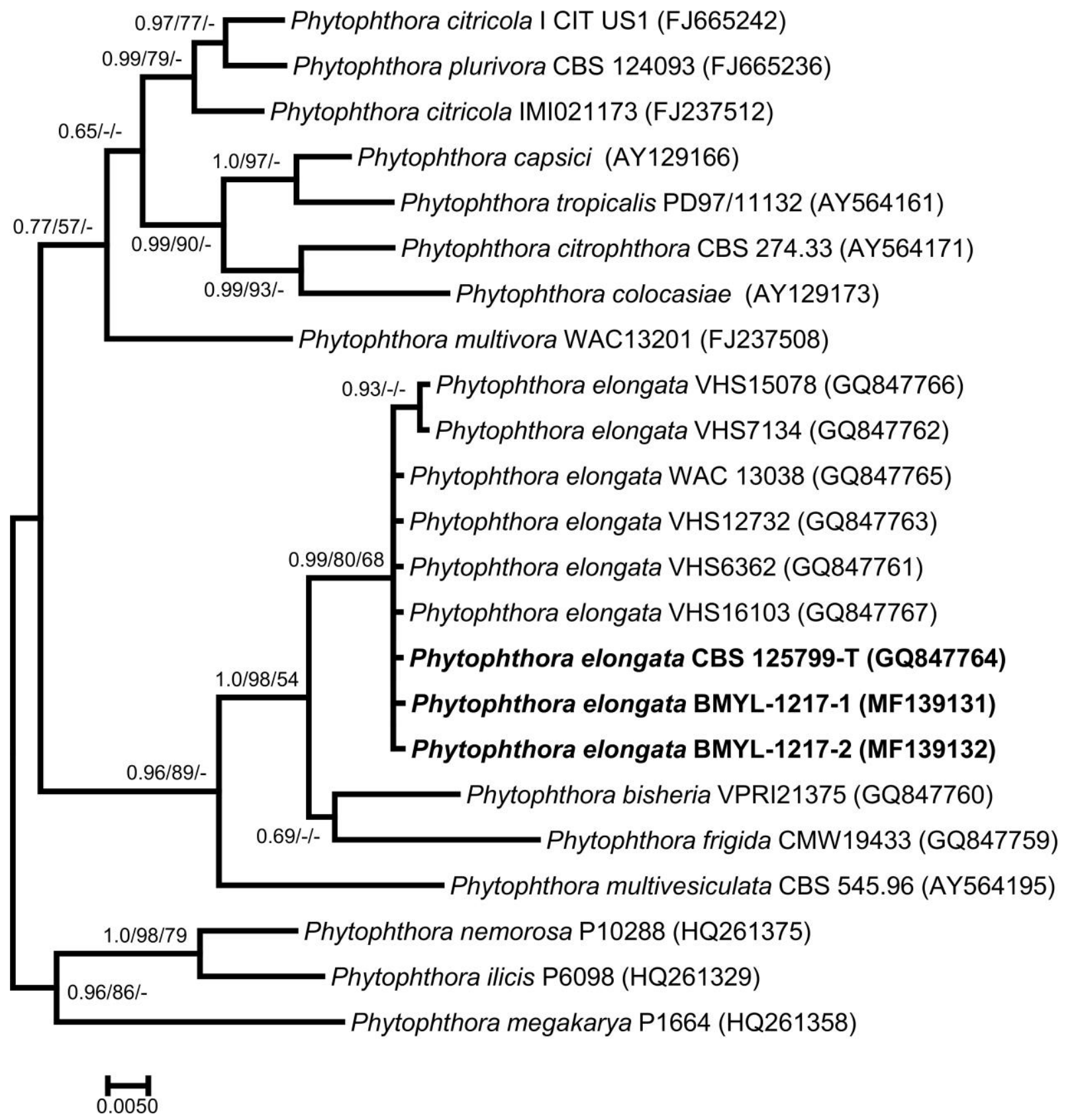

Figure 3 - Bayesian phylogenetic reconstruction of Clade 2 of Phytophthora sensu lato based on cox1 sequences with support values from Bayesian inference, Maximum Likelihood, and Minimum Evolution, in the respective order. CBS 125799 (= VHS13482) is the ex-type culture of $P$. elongata, while the strains BMYL-1217-1 and BMYL-1217-2 are from the Philippines. The scale bar indicates the number of substitutions per site. (-) denotes a lack of support in the respective method.

Of the 10 clades of Phytophthora, Clade 2 was described as one of the largest groups, composed of 21 taxa (Kroon et al. 2012), 17 of which are listed in the Phytophthora database (http://www.phytophthoradb.org/). Clade 2 Phytophthora spp. have been reported as pathogens of a variety of plants, e.g. P. siskiyouensis on Umbellularia californica and Lithocarpus densiflorus (Reeser et al. 2007), P. colocasiae on Colocasia esculenta (Raciborski 1990), P. inflata on Ulmus americana (Caroselli \& Tucker 1949), and P. meadii on Hevea brasiliensis (McRae 1918). These species have been isolated either from the roots, foliage, or fruits of the plant host or from the rhizosphere. 
Table 2 Estuarine Phytophthora spp. as recorded in literature

\begin{tabular}{|c|c|c|c|c|}
\hline Species & Substrate & Country & Clade & Reference \\
\hline P. elongata & Mangrove leaf litter & Philippines & 2 & This study \\
\hline P. estuarina & $\begin{array}{l}\text { Laguncularia racemosa } \\
\text { Rhizophora mangle }\end{array}$ & Brazil & 9 & Guo et al. 2016 \\
\hline P. insolita & $\begin{array}{l}\text { Mangrove leaf litter } \\
\text { Rhizophora }\end{array}$ & $\begin{array}{l}\text { Philippines } \\
\text { China }\end{array}$ & 9 & $\begin{array}{l}\text { Bennett and Thines } 2017 \\
\text { Zeng et al. } 2009\end{array}$ \\
\hline P. inundata & Zostera marina & Netherlands & 6 & Man In 'T Veld et al. 2011 \\
\hline P. gemini & Zostera marina & Netherlands & 6 & Man In 'T Veld et al. 2011 \\
\hline P. rhizophorae & Rhizophora mangle & Brazil & 9 & Guo et al. 2016 \\
\hline
\end{tabular}

Phytophthora elongata has been reported as a pathogen of Eucalyptus marginata from Western Australia (Rea et al. 2010) and is reported in this study as an additional member of the estuarine oomycetes (Table 2) and the first species for the clade 2 group to be isolated from a marine environment. This species was previously considered as a member of the $P$. citricola species complex and referred to as Phytophthora sp. 2 (Burgess et al. 2009), Phytophthora sp. WA2 (Stukely et al. 2007), or P. citricola subgroup SG1 (Bunny 1996, Stukely et al. 2007). The nomenclatural description of $P$. elongata (Rea et al. 2010) stated that sporangia are often elongated, thus the species epithet, and varied in shape from ovoid, obpyriform, elongated obpyriform, ampuliform, limoniform, to various distorted shapes. The Philippine strains produced ovoid, obypriform, and limoniform sporangia, but no elongated sporangia or any sporangial extensions and shape variations were observed during sporulation under the conditions used in this study. These differences in shape could be a reflection of different sporulation conditions used or could be part of the natural variation in this pathogen. Since $P$. elongata is a pathogen of woody angiosperm plants, there is the possibility that this species could be a pathogen of mangrove tree species in the Philippines, which should probably be further investigated in the future. However, it is also conceivable that $P$. elongata has been introduced from Australia together with its hosts, as eucalypts were seen on the bay where the $P$. elongata strains were isolated.

\section{Acknowledgements}

RMB was funded by the Katholischer Akademischer Ausländer Dienst and partially by the Studienstiftung Mykologie. Sampling permits were granted by the Biodiversity and Management Bureau, DENR, the Philippines through the Integrative Fungal Research Cluster (LOEWE-IPF) and UST Collection of Microbial Strains (USTCMS). Support by the LOEWE initiative of the government of Hessen in the framework of the excellence cluster for Integrative Fungal Research (IPF) is gratefully acknowledged.

\section{References}

Bachofer M. 2004 - Molekularbiologische populationsstudien an Plasmopara halstedii, dem falschem mehltau der sonnenblume. PhD dissertation, University of Hohenheim, Stuttgart, Germany.

Bennett RM, Thines M. 2017 - Confirmation that Phytophthora insolita (Peronosporaceae) is present as a marine saprotroph on mangrove leaves and first report of the species for the Philippines. Nova Hedwigia doi: https://doi.org/10.1127/nova_hedwigia/2017/0404

Blair JE, Coffey MD, Park SY, Geiser DM, Kang S. 2008 - A multi-locus phylogeny for Phytophthora utilizing markers derived from complete genome sequences. Fungal Genetics and Biology 45, 266-277.

Bunny FJ. 1996 - The biology, ecology and taxonomy of Phytophthora citricola in native plant communities in Western Australia. Murdoch University, Perth, WA. 
Burgess TI, Webster JL, Ciampini JA, White DW et al. 2009 - Re-evaluation of Phytophthora species isolated during 30 years of vegetation health surveys in Western Australia using molecular techniques. Plant Disease 93, 215-223.

Caroselli NE, Tucker CM. 1949 - Pit canker of elm. Phytopathology 39, 481-488.

Cooke DEL, Drenth A, Duncan JM, Wagels G, Brasier CM. 2000 - A molecular phylogeny of Phytophthora and related Oomycetes. Fungal Genetics and Biology 30, 17-32.

Duniway JM. 1979 - Water relations of water molds. Annual Review of Phytopathology 17, 431460.

Guo JL, Hyde KD, Zhao RL, Hongsanan S et al. 2016 - Fungal diversity notes 253-366: taxonomic and phylogenetic contributions to fungal taxa. Fungal Diversity 78, 1-237.

Ho HH, Jong SC. 1990 - Halophytophthora, gen. nov., a new member of the family Pythiaceae. Mycotaxon 36, 377-382.

Hyde KD, Nilsson RH, Alias SA, Ariyawansa HA et al. 2014 - One stop shop: backbones trees for important phytopathogenic genera: I. Fungal Diversity 67, 21-125.

Hulvey J, Telle S, Nigrelli L, Lamour K, Thines M. 2010 - Salisapiliaceae - a new family of oomycetes from marsh grass litter of southeastern North America. Persoonia 25, 109-116.

Jones EBG, Suetrong S, Sakayaroj J, Bahkali AH et al. 2015 - Classification of marine Ascomycota, Basidiomycota, Blastocladiomycota and Chytridiomycota. Fungal Diversity 73, $1-72$.

Katoh K, Misawa K, Kuma K, Miyata T. 2002 - MAFFT: a novel method for rapid multiple sequence alignment based on fast fourier transform. Nucleic Acid Research 30, 3059-3066.

Kroon LPNM, Bakker FT, van den Bosch GBM, Bonants PJ, Flier WG. 2004 - Phylogenetic analysis of Phytophthora species based on mitochondrial and nuclear DNA sequences. Fungal Genetics and Biology 41, 766-782.

Kroon LPNM, Brouwer H, de Cock AWAM, Govers F. 2012 - The genus Phytophthora Anno 2012. Phytopathology 102, 348-364.

Lara E, Belbahri L. 2011 - SSU rRNA reveals major trends in oomycete evolution. Fungal Diversity 49, 93-100.

Man In 'T Veld WA, Rosendahl KCHM, Brouwer H, De Cock AWAM. 2011 - Phytophthora gemini sp. nov., a new species isolated from the halophilic plant Zostera marina in the Netherlands. Fungal Biology 115, 724-732.

McRae W. 1918 - Phytophthora meadii n. sp. on Hevea brasiliensis. Memoirs of the Department of Agriculture India, Botanical Series 9, 219-273.

Mishra B, Ploch S, Weiland C, Thines M. Unpublished - TrEase-a webserver to infer phylogenetic trees with ease. http://www.thines-lab.senckenberg.de/trease/

Mishra B, Thines M. 2014 - siMBa-a simple graphical user interface for the Bayesian phylogenetic inference program MrBayes. Mycological Progress 13, 1255-1258. doi:10.1007/s11557014-1010-2

Moncalvo JM, Wang HH, Hseu RS. 1995 - Phylogenetic relationships of Ganoderma inferred from the internal transcribed spacers and 25S ribosomal DNA sequences. Mycologia 87, 223 238.

Portales LA. 2004 - Phytophthora diseases in the Philippines. Diversity and Management of Phytophthora in Southeast Asia. ACIAR Monograph 90-102.

Price MN, Dehal PS, Arkin AP. 2010 - FastTree 2 - Approximately maximum-likelihood trees for large alignments. PLoS ONE. 5(3): e9490. doi:10.1371/journal.pone.0009490

Preuett JA, Collins DJ, Luster DG, Widmer TL. 2016 - The effect of salinity on the survival, growth, sporulation and infection of Phytophthora ramorum. Fungal Ecology 23, 123-130.

Raciborski M. 1990 - Parasitic algae and fungi. Java Batavia Bulletin of the New York State Museum 19, 189.

Rea JR, Jung T, Burgess TI, Stukely MJC, Hardy GESJ. 2010 - Phytophthora elongata sp. nov., a novel pathogen from the Eucalyptus marginata forest of Western Australia. Australasian Plant Pathology 39, 477-491. 
Reeser PW, Hansen EM, Sutton W. 2007 - Phytophthora siskiyouensis, a new species from soil, water, myrtlewood (Umbellularia californica) and tanoak (Lithocarpus densiflorus) in southwestern Oregon. Mycologia 99, 639-643.

Robideau GP, de Cock AWAM, Coffey MD, Voglmayr H et al. 2011 - DNA barcoding of oomycetes with cytochrome c oxidase 1 and internal transcribed spacers. Molecular Ecology Resources 11, 1002-1011.

Ronquist F, Teslenko M, van der Mark P, Ayres DL et al. 2012 - MrBayes 3.2: efficient Bayesian phylogenetic inference and model choice across a large model spaces. Systematic Biology 61, 539-542. doi:10.1093/sysbio/sys029

Runge F, Telle S, Ploch S, Savory E et al. 2011 - The inclusion of downy mildews in a multilocus-dataset and its reanalysis reveals a high degree of paraphyly in Phytophthora. IMA Fungus 2, 163-171.

Stamps SJ, Waterhouse GM, Newhook FJ, Hall GS. 1990 - Revised tabular key to the species of Phytophthora. Mycological Papers 162, 1-28.

Stukely MJC, Webster JL, Ciampini JA, Kerp NL et al. 2007 - A new homothallic Phytophthora from the jarrah forest in Western Australia. Australasian Plant Disease Notes 2, 49-51.

Tamura K, Stecher G, Peterson D, Filipski A, Kumar S. 2013 - MEGA6: Molecular evolutionary genetics analysis version 6.0. Molecular Biology and Evolution 30, 2725-2729.

Thines M. 2014 - Phylogeny and evolution of plant pathogenic oomycetes - a global overview. European Journal of Plant Pathology 138, 431-447.

Thines M, Voglmayr H, Göker M. 2009 - Taxonomy and phylogeny of the downy mildews (Peronosporaceae) In Oomycete genetics and genomics: diversity, interactions, and research tools. Lamour K, Kamoun S (eds). John Wiley \& Sons, Inc., Hoboken, NJ, USA. doi. 10.1002/9780470475898.ch3

Waterhouse GM. 1963 - Key to the species Phytophthora de Bary. Mycological Paper No. 92 CMI, Kew, UK.

Zeng HC, Ho HH, Zheng FC. 2009 - A survey of Phytophthora species on Hainan Island of South China. Journal of Phytopathology 157, 33-39. 